MICHAŁ P. ZIEMIAK

https://doi.org/10.33995/wu2019.2.4

\title{
Wynagrodzenie pośrednika ubezpieczeniowego w kontekście ustawy o dystrybucji ubezpieczeń. Zagadnienia wybrane
}

Ustawa o dystrybucji ubezpieczeń - w przeciwieństwie do ustawy o pośrednictwie ubezpieczeniowym - zawiera szereg przepisów, które odnosza się wprost do kwestii wynagrodzenia zarówno pośredników ubezpieczeniowych (agentów i brokerów), jak i pracowników ubezpieczycieli. Przepisy te podzielić możemy na dwie główne kategorie, tj. na dotyczqce samego kształtowania wynagrodzenia oraz dotyczqce zwiqzanych z nim obowiqzków informacyjnych, których beneficjentem jest klient. Tym właśnie zagadnieniom jest poświęcony niniejszy artykuł. Na wstępie omówiono zagadnienia ogólne zwiqzane z wynagradzaniem pośredników ubezpieczeniowych oraz osób, za pomoca których zakład ubezpieczeń wykonuje czynności dystrybucyjne. Dalsze części obejmujq analizę art. 7 ust. 2 ustawy dystrybucyjnej, a także wspomnianych obowiqzków informacyjnych na gruncie tej ustawy (art. 22, 23 i 32). Artykuł zamyka podsumowanie, zawierajace wnioski i uwagi autora.

Słowa kluczowe: pośrednicy ubezpieczeniowi, wynagrodzenie, prowizja, kurtaż, agenci, brokerzy, ubezpieczyciele, dystrybucja ubezpieczeń.

\section{Wstęp}

Wejście w życie z dniem 1 października 2018 roku ustawy o dystrybucji ubezpieczeń ${ }^{1}$ stanowiło nowy etap w regulacji wynagrodzenia pośredników ubezpieczeniowych. Wystarczy przypomnieć, że poprzednio obowiązująca ustawa z dnia 22 maja 2003 roku o pośrednictwie ubezpieczeniowym $^{2}$ o omawianym problemie wspominała tylko w art. 2 ust. 1, zgodnie z którym pośrednictwo

1. Ustawa z dnia 15 grudnia 2017 r. o dystrybucji ubezpieczeń (Dz. U. 2017, poz. 2486 z późn. zm., dalej: u.d.u. lub ustawa dystrybucyjna].

2. Tekst jedn. Dz. U. 2016, poz. 2077, dalej: u.p.u. 
ubezpieczeniowe polegało na wykonywaniu przez pośrednika za wynagrodzeniem czynności faktycznych lub czynności prawnych związanych z zawieraniem lub wykonywaniem umów ubezpieczenia. Przepis ten w żaden sposób nie precyzował, z jakim dokładnie wynagrodzeniem mieliśmy do czynienia. W przypadku agentów ubezpieczeniowych naturalnie odwoływano się do systemu prowizyjnego, którego „trzon” stanowiły przepisy Kodeksu cywilnego ${ }^{3}$ o umowie agencyjnej, zwłaszcza art. $758^{1}$ k.c. ${ }^{4}$ Odnośnie do brokerów ubezpieczeniowych kwestia wynagrodzenia pozostawała de facto w sferze regulacji umownej oraz ustalonych zwyczajów ${ }^{5}$. Jego podstawowa formą był oczywiście kurtaż brokerski, przy czym wskazywano także na możliwość uzyskiwania przez brokera innych dochodów, niekoniecznie od zakładu ubezpieczeń (jako płatnika kurtażu), np. z tytułu wykonywania czynności likwidacyjnych na rzecz klienta ${ }^{6}$. Poza art. 2 u.p.u. nie istniały jednak żadne przepisy dotyczące wprost wynagrodzenia pośredników ubezpieczeniowych. Jeszcze przed uchwaleniem u.d.u. organ nadzoru (KNF) próbował wypełnić wskazana pustkę legislacyjną m.in. rekomendacjami i wytycznymi, takimi jak choćby Wytyczne dla zakładów ubezpieczeń dotyczace dystrybucji ubezpieczeń? czy Rekomendacje dla zakładów ubezpieczeń dotyczqce badania adekwatności produktu ${ }^{8}$, stanowiące próbę reakcji m.in. na zjawisko missellingu. Wreszcie, wejście w życie ustawy z dnia 11 września 2015 roku o działalności ubezpieczeniowej i reasekuracyjnej ${ }^{9}$ oznaczało pojawienie się w polskim prawie ubezpieczeniowym pewnych „przepisów kierunkowych" dotyczących ustalania wynagrodzenia w przypadku umowy ubezpieczenia z ubezpieczeniowym funduszem kapitałowym (UFK) lub umowy, w której wysokość świadczenia jest ustalana w oparciu o określone indeksy lub inne wartości bazowe ${ }^{10}$.

Powyższa sytuacja - przynajmniej w pewnych aspektach - ulegała zmianie, z chwila, w której obowiązywać zaczęła u.d.u. Choć sama istota czy charakter prawny wynagrodzenia pośredników nie uległy zmianie (tzn. nadal mamy do czynienia z, co do zasady, systemem prowizyjnym oraz kurtażowym), to jednak ustawa dystrybucyjna wprowadziła pewne kryteria dotyczące

3. Ustawa z dnia 23 kwietnia 1964 r. - Kodeks cywilny [tekst jedn. Dz. U. 2018, poz. 1025, dalej: k.c.).

4. Zob. E. Wieczorek, Komentarz do ustawy o pośrednictwie ubezpieczeniowym, [w:] Prawo ubezpieczeń gospodarczych. Tom I. Komentarz, [red.] Z. Brodecki, M. Glicz, M. Serwach, Wolters Kluwer, LEX/el. 2010 (komentarz do art. 2, pkt IV.1 i nast.). Zob. też wyrok SN z dnia 12 stycznia 2012 r., IV CSK 215/11 (Legalis nr 464034), zgodnie z którym do należnego wynagrodzenia agenta ubezpieczeniowego stosuje się art. $761 \S 1$ k.c.

5. Zob. E. Wieczorek, op. cit. (pkt. V.1 i nast.).

6. Zob. E. Kowalewski, [w:] Prawo ubezpieczeń gospodarczych, [red.] E. Kowalewski, Oficyna Wydawnicza Branta, Bydgoszcz-Toruń, 2006, s. 454 oraz tenże, Wynagrodzenie brokera ubezpieczeniowego, „Prawo Asekuracyjne" 2008, nr 2, s. 3 i nast.

7. Zob. Wytyczne dla zakładów ubezpieczeń dotyczqce dystrybucji ubezpieczeń, stanowiące załącznik do uchwały nr 184/2014 Komisji Nadzoru Finansowego z dnia 24 czerwca 2014 r. (Dz. Urz. KNF 2014, poz. 13), w których czytamy m.in., że: „wynagrodzenie agenta ubezpieczeniowego z tytułu oferowania produktów ubezpieczeniowych powinno być ustalane przy uwzględnieniu ponoszonych przez niego kosztów" (wytyczna 10).

8. Zob. Rekomendacje dla zakładów ubezpieczeń dotyczqce badania adekwatności produktu, stanowiące załącznik do uchwały nr 228/2016 Komisji Nadzoru Finansowego z dnia 22 marca 2016 r. (Dz. Urz. KNF 2016, poz. 10) w sprawie rekomendacji dla zakładów ubezpieczeń dotyczących badania adekwatności produktu, w których z kolei czytamy m.in., że: „zakład ubezpieczeń powinien monitorować proces sprzedaży i ustalić zasady wynagradzania, które ograniczają ryzyko oferowania produktów niedostosowanych do potrzeb i możliwości klientów" (rekomendacja 17.1.).

9. Tekst jedn. Dz. U. 2019, poz. 381 (dalej: u.dz.u.r.).

10. Chodzi tu 0 art. 23 ust. 5 i 6 oraz 24 ust. 3 i 4 u.dz.u.r. 
kształtowania wynagrodzeń oraz stosowne obowiazki informacyjne w tym zakresie. Stąd, celem niniejszego artykułu jest próba analizy uregulowań wskazanej ustawy, zwłaszcza zaś kluczowych jej przepisów tzn.:

- $\quad$ art. 7 ust. 2, zgodnie z którym sposób wynagradzania dystrybutora ubezpieczeń oraz osób, przy pomocy których wykonywane są czynności agencyjne lub czynności brokerskie w zakresie ubezpieczeń, oraz osób, przez które wykonywane są czynności dystrybucyjne zakładu ubezpieczeń, nie może być sprzeczny z obowiązkiem działania zgodnie z najlepiej pojętym interesem klientów, w szczególności dystrybutor ubezpieczeń nie może dokonywać ustaleń dotyczących wynagrodzeń, celów sprzedaży lub innych ustaleń, które mogłyby stanowić zachętę do proponowania klientowi określonej umowy ubezpieczenia lub umowy gwarancji ubezpieczeniowej, w sytuacji gdy dystrybutor ubezpieczeń mógłby zaproponować inną umowę, która lepiej odpowiadałaby potrzebom klienta;

- $\quad$ art. 22, 23 i 32 w zakresie, w jakim regulują one obowiązki informacyjne dotyczące wynagrodzenia odpowiednio agentów, agentów oferujących ubezpieczenia uzupełniające, zakładów ubezpieczeń oraz brokerów.

Głównym przedmiotem rozważań będzie dalej problematyka związana z wynagradzaniem pośredników ubezpieczeniowych, a więc agentów i brokerów ubezpieczeniowych. Stąd powyższe zagadnienie w spektrum odnoszącym się wprost do zakładów ubezpieczeń (m.in. art. 23 u.d.u.) zostanie omówione posiłkowo.

\section{Artykuł 7 ust. 2 ustawy dystrybucyjnej jako „wytyczna kierunkowa” w kształtowaniu wynagrodzenia pośrednika ubezpieczeniowego}

Dla porządku dalszych wywodów wskazać należy, że zgodnie z art. 3 ust. 1 pkt 15 u.d.u. pod pojęciem pośrednika ubezpieczeniowego rozumie się agenta ubezpieczeniowego, agenta oferujacego ubezpieczenia uzupełniające, brokera ubezpieczeniowego oraz brokera reasekuracyjnego, którzy wykonują dystrybucję ubezpieczeń albo dystrybucję reasekuracji za wynagrodzeniem. Samo zaś wynagrodzenie zostało zdefiniowane w punkcie 22 tego przepisu - jest nim prowizja, honorarium, opłata lub inna płatność, w tym korzyść ekonomiczna jakiegokolwiek rodzaju lub inna korzyść lub zachęta finansową lub niefinansowa, oferowane lub przekazywane w związku z działalnością w zakresie dystrybucji ubezpieczeń. Definicja wynagrodzenia jest więc wyjątkowo szeroka i dotyczy korzyści otrzymywanych przez pośrednika zarówno od zakładu ubezpieczeń, jak i od innych podmiotów ${ }^{11}$. Można też spokojnie przyjąc, że obejmuje ona wszystkie formy wynagrodzenia wypłacane pośrednikom czy pracownikom zakładów ubezpieczeń Niestety, wywołuje ona również pewne wątpliwości - chodzi tu o objęcie zakresem definicji „zachęty niefinansowej”. Jak się wydaje, ustawodawca zrównał formy finansowe i niefinansowe, choć w doktrynie pojawiaja

11. Zob. P. Machulak, [w:] Ustawa o dystrybucji ubezpieczeń. Komentarz, [red.] P. Machulak, J. Ziemba, CH Beck, Warszawa 2018, s. 35-36. Powołany Autor podnosi, że przepis ten wywołuje wątpliwości m.in. w kwestii, czy szkolenia organizowane przez zakład ubezpieczeń (np. dla agentów) należałoby kwalifikować jako korzyść [trafnie odrzucając jednak taki pogląd w oparciu o wykładnię celowościową). 
się także głosy, iż „zachęta niefinansowa” została potraktowana de facto jako przykład wynagrodzenia o czysto finansowym charakterze ${ }^{12}$.

Zgodnie z art. 7 ust. 2 u.d.u. sposób wynagradzania pośrednika nie może stać w sprzeczności z obowiązkiem działania zgodnie z najlepiej pojętym interesem klientów ${ }^{13}$. Stąd na wstępie rozszyfrować należy pojęcie „najlepiej pojętego interesu klienta” jako sui generis klauzuli generalnej w ustawie dystrybucyjnej. W doktrynie wskazuje się, że działanie zgodnie z najlepiej pojętym interesem klienta będzie takim działaniem, które scharakteryzować można jako „sprawiedliwe, uczciwe, z uwzględnieniem najwyższego poziomu rzetelnej i wyczerpującej informacji oraz z uwzględnieniem potrzeb klienta, na podstawie profesjonalnej analizy przeprowadzanej zgodnie z art. 8 ust. 1 u.d.u." ${ }^{14}$. Inaczej mówiąc, chodzi o należyte wypełnienie i wykonanie wszelkich obowiązków (w tym informacyjnych] wynikających z przepisów u.d.u. ${ }^{15}$, prowadzące do zaproponowania optymalnej (tj. uwzględniającej potrzeby i wymagania klienta) umowy ubezpieczenia (gwarancji), przy czym za trafny uznać należy pogląd, zgodnie z którym wskazany obowiązek należy różnicować względem konkretnych kategorii dystrybutorów ${ }^{16}$.

Dyspozycją artykułu ? ust. 2 u.d.u. objęci są: agenci (w tym multiagenci oraz agenci oferujący ubezpieczenia uzupełniające] i brokerzy ubezpieczeniowi, osoby wykonujące czynności agencyjne w imieniu agentów (tzw. OWCA lub OFWCA) oraz czynności brokerskie w imieniu brokerów [tzw. OWCB], osoby przez które wykonywane są czynności dystrybucyjne zakładu ubezpieczeń, a także przedsiębiorcy wykonujący działalność w zakresie dystrybucji ubezpieczeń, do których z mocy art. 2 u.d.u. nie stosuje się przepisów tej ustawy ${ }^{17}$.

12. Zob. odnośnie do wewnętrznych sprzeczności definicji wynagrodzenia: M. Szczepańska, Wynagrodzenie brokera ubezpieczeniowego w świetle ustawy o dystrybucji ubezpieczeń, „Prawo Asekuracyjne” 2018, nr 3, s. 22-23.

13. Przepis ten stanowi de facto powtórzenie motywu 46 preambuły dyrektywy Parlamentu Europejskiego i Rady (UE) 2016/97 z dnia 20 stycznia 2016 r. w sprawie dystrybucji ubezpieczeń (Dz. Urz. UE 26, z dnia 2 lutego 2016 r., s. 19-59, dalej: IDD), państwa członkowskie powinny wymagać, aby stosowana przez dystrybutorów produktów ubezpieczeniowych polityka wynagradzania pracowników lub przedstawicieli nie wpływała negatywnie na ich zdolność do działania zgodnie z najlepiej pojętym interesem klienta ani nie uniemożliwiała im wydawania odpowiednich rekomendacji lub przedstawiania informacji w uczciwej, jasnej i niewprowadzajacej $w$ błąd formie. Wynagrodzenie oparte na wynikach sprzedaży nie powinno być zachętą do proponowania klientowi określonego produktu. Zob. w tym zakresie też art. 17 ust. 3 IDD.

14. Zob. J. Nowak, [w:] Ustawa o dystrybucji ubezpieczeń. Komentarz, [red.] P. Czublun, CH Beck, Warszawa 2018, s. 72 i nast.

15. Zob. P. Machulak, op. cit., s. 60.

16. Np. agent ubezpieczeniowy - mając na uwadze obowiązek lojalności także wobec zakładu ubezpieczeń - nie musi drobiazgowo analizować potrzeb klienta, tak jak broker ubezpieczeniowy. Zob. K. Malinowska, Najlepszy interes klienta - rozważania na tle ustawy o dystrybucji ubezpieczeń, s. 120-121 oraz M. Orlicki, Aksjologia dystrybucji ubezpieczeń - kryteria uznawania działań dystrybutora za zgodne z prawem i etyczne, s. 24, [w:] Dystrybucja usług ubezpieczeniowych. Wybrane zagadnienia prawne, [red.] B. Gnela, M. Szaraniec, DIFIN, Warszawa 2017.

17. Zob. art. 3 ust. 3 pkt 2) u.d.u., zgodnie z którym w przypadku wykonywania działalności w zakresie dystrybucji ubezpieczeń przez wskazanego przedsiębiorcę zakład ubezpieczeń zapewnia wykonanie obowiązków i spełnienie wymogów, o których mowa w art. ?, art. 8 ust. 3 i art. 10 ustawy. 
Wynagrodzenie pośrednika przyjmować może zróżnicowane formy, na co zresztą wskazuje sama ustawa dystrybucyjna ${ }^{18}$. W przypadku pośredników, o czym była już mowa, a także podmiotów, o których mowa w art. 2 u.d.u., zasadniczą forma pozostaje prowizja (agenci) lub kurtaż (brokerzy), choć zwłaszcza w przypadku tych drugich nie można wykluczyć też wynagrodzenia płaconego bezpośrednio przez klienta (np. za dodatkowe ekspertyzy czy opinie zlecane brokerowi $^{19}$ ). Odnośnie do OWCA oraz OWCB, wynagrodzenie może przybrać formę honorarium z umowy o pracę lub z umowy prawa cywilnego (przeważnie zlecenia lub o świadczenie usług), w tym także zawartej w ramach prowadzonej przez OWCA lub OWCB działalności gospodarczej. W przypadku umów o pracę może być to wynagrodzenie stałe, połączone z systemem premiowania (tzw. zmienne składniki wynagrodzenia), zaś w przypadku umów prawa cywilnego za dopuszczalne uznać należy zarówno wynagrodzenia ryczałtowe, jak i prowizyjne, bądź stanowiące kombinację obu wskazanych. Co się zaś tyczy osób, za pomocą których zakład ubezpieczeń wykonuje czynności dystrybucyjne, to zgodnie z art. 4 ust. 5 u.d.u. zakład ubezpieczeń może wykonywać bezpośrednio czynności w zakresie dystrybucji ubezpieczeń przez uprawnionego przez ten zakład ubezpieczeń pracownika. Choć ustawa dystrybucyjna nie definiuje pojęcia pracownika, należy przyjąć, że chodzi tu o pracownika w rozumieniu przepisów prawa pracy. To z kolei oznacza, że wynagrodzenie wskazanych osób będzie wynagrodzeniem z umowy o pracę, które może być łączone ze wspomnianym systemem premiowania (składniki zmienne). Wspomniane systemy wynagrodzenia prowizyjnego możemy podzielić na prowizje wyliczane bezpośrednio (odnoszące się do zawierania umów ubezpieczenia) oraz wyliczane pośrednio (odnoszące się np. do wyników sprzedaży) 20 .

Artykuł 7 ust. 2 u.d.u. wskazuje przykład nieprawidłowego kształtowania wynagrodzenia pośrednika, a mianowicie uzależnienie wynagrodzenia od konkretnych celów sprzedażowych, które prowadziłyby do wypaczenia wspomnianego celu, jakim jest zaoferowanie umowy optymalnej. Użycie we wskazanym przepisie zwrotu „w szczególności” oznacza, że katalog niedozwolonych ustaleń w zakresie wynagradzania dystrybutorów jest otwarty, ergo musi być podporzadkowany ogólnej zasadzie działania w najlepiej pojętym interesie klienta. W doktrynie zasadnie przyjmuje się, że ustalanie celów sprzedażowych czy też stosowanie np. powiększonych stawek prowizji (nadprowizji lub prowizji „bonusowych” badź konkursów sprzedażowych) nie zostało po wejściu w życie ustawy dystrybucyjnej zakazane ${ }^{21}$. Wręcz przeciwnie, tego rodzaju zasady wynagradzania np. agentów są dopuszczalne, o ile nie stanowią zachęty do proponowania nieoptymalnych umów ubezpieczenia. Problem tkwi w braku definicji pojęcia zachęty, którym posługuje się art. ? ust. 2. W doktrynie ${ }^{22}$ wskazuje się na możliwość odwołania się w drodze analogii do przepisów

18. Zob. chociażby art. 22 ust. 1 pkt 5 czy art. 32 ust. 1 pkt 6 ustawy, których szersze omówienie znajduje się w dalszej części niniejszego artykułu.

19. Choć nie można wykluczyć także płatności wynagrodzenia sensu stricto za wykonanie usługi brokerskiej (a więc kurtażu) także bezpośrednio przez klienta.

20. M. Szczepańska, op. cit., s. 23.

21. Zob. J. Pokrzywniak, [w:] Nowe zasady dystrybucji ubezpieczeń. Zagadnienia prawne, [red.] J. Pokrzywniak, Wolters Kluwer, Warszawa 2018, s. 152-154. Autor ten trafnie wskazuje też na stanowisko European Insurance and Occupational Pensions Authority (EIOPA] wyrażone w dokumencie Technical Advice on possible delegated acts concerning the Insurance Distribution Directive, w którym EIOPA nie wyklucza stosowania systemów dodatkowego wynagradzania dystrybutorów, a jedynie postuluje konieczność ich konstruowania w zgodzie z przepisami IDD i dokonywania całościowych ocen ich funkcjonowania.

22. Zob. J. Nowak, [w: ] Ustawa o dystrybucji ..., [red.] P. Czublun, s. ?7-79. 
rozporządzenia delegowanego Komisji UE 2017/235923 oraz przewidzianego tam testu systemów zachęt (art. 8 ust. 2 rozporządzenia). Test opiera się m.in. na sprawdzeniu, czy:

- zachęta lub system zachęt opierają się wyłącznie lub w przeważajacym stopniu na ilościowych kryteriach handlowych, czy też uwzględniaja odpowiednie kryteria jakościowe odzwierciedlajace zgodność z właściwymi przepisami, jakość usług świadczonych klientom i zadowolenie klienta; lub

- czy zachęta jest wypłacana w całości lub w znacznej części w chwili zawarcia umowy ubezpieczenia, czy też jej wypłata rozkłada się na cały czas trwania umowy; lub

- istnieje odpowiedni mechanizm odzyskiwania zachęty w przypadku wygaśnięcia ważności produktu lub jego wykupu na wczesnym etapie lub w przypadku wyrządzenia szkody interesom klienta.

Jak się wydaje, powyższe kryteria mogạ pomóc w ustaleniu, czy stosowane systemy premiowania lub konkursy sprzedażowe odpowiadaja dyspozycji art. $?$ ust. 2 ustawy dystrybucyjnej. Podsumowując, skoro umowa ubezpieczenia ma być zgodna z potrzebami klienta (a zaoferowanie takiej umowy jest przejawem działania w jego najlepiej pojętym interesie w rozumieniu art. $?$ u.d.u.], to rzetelne przeprowadzenie analizy potrzeb i wymagań klienta z art. 8 u.d.u. powinno być warunkiem koniecznym zastosowania danego systemu wynagradzania pośrednika, zwłaszcza wynagrodzenia dodatkowego. Ustawa dystrybucyjna z pewnością nie zabrania stosowania wskazanych wcześniej systemów premiowania czy konkursów sprzedażowych, o ile ich warunki nie naruszają dyspozycji art. $?$ ust. 2. Jednak to po stronie ubezpieczyciela lub pośrednika spoczywa ciężar wykazania, że warunki prowizyjne czy konkursowe są zgodne z litera prawa. Z tych względów postulować należy wprowadzenie sui generis systemów checks-and-balances, tj. stosowanie w regulaminach premiowania czy konkursach sprzedażowych klauzul nakładających stosowne obowiązki, ukierunkowane na zabezpieczenie interesu klienta. Chodzi więc o zapewnienie równowagi pomiędzy założonymi celami sprzedażowymi a koniecznością oferowania optymalnych dla klienta umów ubezpieczenia. W doktrynie wskazuje się tu następujące rozwiązania:

- wprowadzenie mechanizmów badania poziomu satysfakcji klientów, którzy zawarli konkretna umowę ubezpieczenia, lub wprowadzenie dodatkowych kryteriów oceny, takich jak np. wskaźniki retencji (utrzymania klientów) czy liczby składanych przez klientów reklamacji24;

- wprowadzenie mechanizmów badania wypełniania przez pracowników zakładów ubezpieczeń czy agentów nałożonych nań obowiązków przedkontraktowych (np. analizy wymagań i potrzeb klienta ${ }^{25}$.

23. Zob. Rozporządzenie delegowane Komisji (UE) 2017/2359 z dnia 21 września 2017 r. uzupełniające dyrektywę Parlamentu Europejskiego i Rady (UE) 2016/97 w odniesieniu do wymogów informacyjnych i zasad prowadzenia działalności mających zastosowanie do dystrybucji ubezpieczeniowych produktów inwestycyjnych (Dz. Urz. UE nr 341 z dnia 20 grudnia 2017 r., s. 8-18). Zgodnie z 2 ust. 2 rozporządzenia „zachęta” oznacza każdą opłatę, prowizję lub korzyść niepieniężną przekazaną przez pośrednika lub zakład w związku z dystrybucją ubezpieczeniowego produktu inwestycyjnego na rzecz dowolnej strony innej niż klient uczestniczący w przedmiotowej transakcji lub osoba działająca w imieniu tego klienta, jak również każdą opłatę, prowizję lub korzyść otrzymaną przez pośrednika lub zakład od takiej dowolnej strony innej niż klient uczestniczący w przedmiotowej transakcji lub osoba działająca w imieniu tego klienta. „Systemem” zachęt jest zaś zbiór zasad regulujących wypłacanie zachęt, w tym warunki, na których zachęty są wypłacane.

24. Zob. P. Machulak, op. cit., s. 63.

25. Zob. J. Pokrzywniak, op. cit., s. 153. 
Poza podanymi wcześniej, można wskazać jeszcze inne „zabezpieczenia” umowne ${ }^{26}$ należytego ukształtowania sposobu wynagradzania pośredników czy osób, za pomocą których zakład ubezpieczeń wykonuje czynności dystrybucyjne, a mianowicie:

- klauzule dodatkowo zobowiązujace do pełnej realizacji obowiązku przeprowadzenia analizy potrzeb i wymagań klienta (i udokumentowania tej analizy);

- klauzule przewidujące, że umowy uwzględniane przy wyliczaniu prowizji bądź w systemie premiowania lub w konkursie, które zostały rozwiązane, nie będą uwzględniane przy ustalaniu prawa do premii czy nagrody;

- $\quad$ klauzule zobowiązujące do zwrotu prowizji, premii czy nagrody już wypłaconej w razie rozwiązania umowy uwzględnionej w systemie premiowania czy konkursie sprzedażowym - jak się wydaje ten mechanizm może okazać się kluczowy w egzekwowaniu należytego wynagradzania zwłaszcza agentów oraz OWCA²

- klauzule przewidujące rozłożenie wypłaty prowizji w czasie, w przypadku umów długoterminowych (np. umów ubezpieczenia na życie).

Oczywiście poza wprowadzaniem samych postanowień do umów czy regulaminów, należałoby także przeprowadzać okresowe oceny stosowanych systemów premiowania lub konkursów sprzedażowych, celem wykrycia ewentualnych nieprawidłowości czy ich „słabych stron”.

Jakie więc praktyczne implikacje niesie stosowanie art. 7 ust. 2 ustawy reklamacyjnej dla pośredników ubezpieczeniowych? Z pewnością będą one różne, w zależności od tego, czy mamy do czynienia z agentami ( $w$ tym agentami oferującymi ubezpieczenia uzupełniające), czy brokerami.

W przypadku agentów ubezpieczeniowych należy pamiętać, że poza ustawą dystrybucyjną przy kształtowaniu wynagrodzenia agentów wciąż należy brać pod uwagę wspomniane Wytyczne dla zakładów ubezpieczeń dotyczqce dystrybucji ubezpieczeń, a dokładnie wytyczną 10, zgodnie z którą „wynagrodzenie agenta ubezpieczeniowego z tytułu oferowania produktów ubezpieczeniowych powinno być ustalane przy uwzględnieniu ponoszonych przez niego kosztów". Idąc dalej, dopuszczalne jest różnicowanie wysokości prowizji od wysokości składki, pod warunkiem zachowania proporcji „wyższa składka równa się szerszy zakres ochrony ubezpieczeniowej” czy też dodatkowe premiowanie agenta wyłącznego ${ }^{28}$. Najwięcej wątpliwości zdaje się wywoływać kwestia wynagradzania multiagentów. W piśmiennictwie zarysowały się dwa poglądy. Zgodnie z pierwszym zakład ubezpieczeń może dążyć do tego, aby wynagrodzenie, które otrzymuje od niego multiagent, kształtowało się na wyższym poziomie (lub było w inny sposób korzystniejsze) niż to otrzymywane przez multiagenta od konkurencji29. Inaczej mówiąc, to, że zakład „X” oferuje wyższe prowizje niż zakład „Y”, nie oznacza, że umowy ubezpieczenia zakładu „X” są mniej korzystne od umów zakładu „Y”. To na multiagencie spoczywa obowiązek analizy wymagań i potrzeb klienta i doboru właściwej umowy ubezpieczenia, a wynagrodzenie należne od danego ubezpieczyciela

26. Chodzi tu zarówno o treść m.in. umów o pracę, umów agencyjnych, regulaminów premiowania, jak i regulaminów konkursów sprzedażowych stosowanych przez dystrybutorów.

27. W przypadku OWCA czy OWCB zatrudnionych w oparciu o umowę o pracę skuteczne wyegzekwowanie zwrotu prowizji - ze względu na szczególną ochronę wynagrodzenia pracowniczego wynikającą z przepisów prawa pracy - może okazać się jednak niemożliwe. Stąd w przypadku tego modelu współpracy z OWCA czy OWCB należy postulować alternatywne rozwiązania, np. niewiązanie prowizji agenta, multiagenta czy brokera zatrudniającego z prowizją OWCA czy OWCB (a więc wprowadzenie de facto sztywnego systemu wynagradzania).

28. Zob. J. Nawracała, Wynagrodzenie w dystrybucji (cz. 2), „Miesięcznik Ubezpieczeniowy” 2017, nr 12, s. 39.

29. Zob. P. Machulak, op. cit., s. 64. 
ma tu znaczenie drugorzędne. Zgodnie zaś z drugim stanowiskiem zakłady ubezpieczeń powinny uwzględniać realia rynkowe i kształtować stawki oraz sposoby wynagradzania multiagentów odpowiadające średnim rynkowym ${ }^{30}$. Jak się wydaje, do odwoływania się do średnich rynkowych szczególnie wobec braku wyraźnych regulacji w tym zakresie - podchodzić należy z pewną dozą ostrożności, uwzględniając kwestie chociażby nakładu pracy pośrednika, stopień skomplikowania produktu ubezpieczeniowego czy rynek docelowy, na którym ma on być oferowany. Mimo regulacji zawartej w art. $?$ ust. 2 ustawy dystrybucyjnej, wysokość wynagrodzenia i jego atrakcyjność, nadal stanowią ważny element konkurencji na rynku ubezpieczeń. Poza tym zdarzają się przypadki, w których multiagent ma w swej ofercie produkt, oferowany tylko przez jeden zakład ubezpieczeń, nieposiadający alternatywy co do zakresu ochrony czy ubezpieczanych ryzyk - w takiej sytuacji kształtowanie wysokości wynagrodzenia ograniczone winno być tylko dyspozycją art. 7 ust. 2 u.d.u. oraz wytycznymi dystrybucyjnymi KNF ${ }^{31}$.

Dodatkowo w zakresie umów ubezpieczenia na życie - z UFK lub w których wysokość świadczenia jest ustalana w oparciu o określone indeksy lub inne wartości bazowe - zakłady ubezpieczeń muszą stosować art. 23 ust. 5 i 6 oraz 24 ust. 3 i 4 u.dz.u.r., tj. kierować się zasadą równomiernego rozłożenia w czasie wydatków z tytułu prowizji pośrednika ubezpieczeniowego w okresie ubezpieczenia określonym w umowie ubezpieczenia ${ }^{32}$.

Wskazane powyżej uwagi dotyczące agentów i multiagentów odnieść należy także do agentów oferujących ubezpieczenia uzupełniające oraz przedsiębiorców, o których mowa wart. 2 ustawy dystrybucyjnej. W ostatnim przypadku pamiętać trzeba, że obowiązek zagwarantowania stosowania art. $?$ ust. 2 u.d.u. spoczywa na zakładzie ubezpieczeń, przy czym art. 2 nie wymaga od przedsiębiorców zwolnionych spod rygorów ustawy przeprowadzania analizy wymagań i potrzeb klienta. Niemniej zastosowanie znajduje tu art. 8 ust. 3 ustawy dystrybucyjnej, a więc konieczność zaoferowania umowy optymalnej, zgodnie z wcześniejszymi uwagami.

Co się zaś tyczy brokerów ubezpieczeniowych, to nadal podstawą wypłaty wynagrodzenia będą porozumienia kurtażowe, określające w szczególności zasady nabycia, wysokość i terminy płatności prowizji brokerskiej. Należy zgodzić się z Jakubem Nawracałą, że niedopuszczalne jest - zarówno w świetle art. $?$ ust. 2 ustawy dystrybucyjnej, jak i istoty zawodu brokera - stosowanie przez zakłady ubezpieczeń systemów premiowania czy konkursów sprzedażowych adresowanych do brokerów, które promowałyby produkty danego ubezpieczyciela ${ }^{33}$. Inaczej mówiąc, wynagrodzenie brokera ubezpieczeniowego musi być oparte wyłącznie o „czysty kurtaż”, bez odwoływania się do takich czynników, jak plany sprzedaży czy współczynniki szkodowości ${ }^{34}$. Powyższe nie wyklucza jednak wewnętrznego premiowania OWCB za osiaggnięcie konkretnych wyników w ramach struktury danego brokera, np. poprzez split kurtażu pomiędzy brokerem a OWCB, czy stosowanie regulaminów premiowania ${ }^{35}$. Odnośnie zaś do kształtowania wysokości stawek kurtażu w relacji zakład ubezpieczeń - broker poczynić należy analogiczne uwagi, jak w przypadku multiagentów.

30. Zob. m.in. J. Pokrzywniak, op. cit., s. 155.

31. Tak też J. Nawracała, op. cit., s. 39.

32. Zob. więcej M. Szczepańska, [w:] Ustawa o działalności ubezpieczeniowej i reasekuracyjnej. Komentarz, [red.] M. Szczepańska, P. Wajda, Wolters Kluwer, Warszawa 2017, s. 189-190.

33. Zob. J. Nawracała, op. cit., s. 39-40.

34. Ibidem.

35. Oczywiście pod warunkiem, że stosowane systemy premiowania odpowiadają dyspozycji art. 7 ust. 2 u.d.u. 
Wreszcie, podać należy pewne przykłady systemów wynagradzania pośredników ubezpieczeniowych, które z góry budzą wạtpliwości w kontekście zgodności z dyspozycją art. 7 ust. 2. ustawy dystrybucyjnej. Jakub Nawracała wskazuje tu na ${ }^{36}$ :

- stosowanie zróżnicowanej prowizji w stosunku do alternatywnych wobec siebie produktów o zróżnicowanym zakresie ochrony i innych warunkach ubezpieczenia;

- stosowanie zróżnicowanej prowizji względem wariantów tego samego produktu ubezpieczeniowego, gdzie wybór „wyższego wariantu” nie znajduje uzasadnienia np. w nakładzie pracy dystrybutora przy oferowaniu tego produktu;

Przywołany Autor sceptycznie odnosi się także do uwzględniania współczynnika szkodowości w systemach premiowania czy konkursach sprzedażowych, które to praktyki - jego zdaniem - moga prowadzić do missellingu. Obawy te są uzasadnione, gdyż perspektywa uzyskania dodatkowego wynagrodzenia z powodu niskiego poziomu szkodowości z danej umowy może skutkować oferowaniem nieoptymalnych umów, tak aby zagwarantować niski współczynnik wypłat świadczeń. Niemniej nie można całkowicie wykluczyć możliwości posługiwania się współczynnikiem szkodowości, jeżeli powiążemy go np. z zastosowanymi przez ubezpieczającego (ubezpieczonego] mechanizmami prewencji ubezpieczeniowej. Przykładowo, jeżeli na skutek zwiększenia poziomu bezpieczeństwa pożarowego w przedsiębiorstwie, w którym często dochodziło do pożarów, współczynnik szkodowości (w porównaniu z poprzednimi okresami ubezpieczenia) spadnie, to dopuszczalne - jak się wydaje - będzie wynagrodzenie pracownika zakładu ubezpieczeń dodatkowa premią, jeżeli to z jego inicjatywy zostały wydane zalecenia zastosowania w tym przedsiębiorstwie nowych rozwiązań ppoż. obniżających ryzyko pożaru.

Bogactwo możliwych stanów faktycznych czy okoliczności, z jakimi powiązać można prawo pośrednika (zwłaszcza agenta i multiagenta) do wynagrodzenia, nie pozwala na ustalenie zamkniętego katalogu niedozwolonych praktyk w omawianym zakresie. Z pewnością ponad wszelką wạtpliwość należy wykluczyć możliwość stosowania wysokich prowizji za dystrybucję produktów, których „przydatność” dla klienta jest znikoma, a więc które kolokwialnie określić możemy jako „kiepskie”. Z kolei wykluczyć nie można np. dodatkowej prowizji dla agenta z tytułu wdrożenia nowego i bardziej skomplikowanego systemu komputerowego do obsługi zawieranych przez niego umów ubezpieczenia. Już te dwa przykłady pokazują, jak ważne będą tu standardy rynkowe wypracowane przez dystrybutorów w oparciu o przepisy ustawy dystrybucyjnej.

\section{Obowiązki informacyjne pośredników ubezpieczeniowych w zakresie wynagrodzenia}

Ustawa dystrybucyjna nałożyła na zakłady ubezpieczeń oraz pośredników ubezpieczeniowych konkretne obowiązki informacyjne odnoszące się wprost do kwestii wynagrodzenia. Obowiązki te maja charakter stricte przedkontraktowy ${ }^{37}$, gdyż w każdym przypadku (vide wspomniane art. 22, 23 i 32 ) informacja o wynagrodzeniu - jako element „pakietu informacyjnego” - musi zostać przekazana „przed” zawarciem umowy ubezpieczenia lub gwarancji. Odwołując się do IDD, a dokładnie

36. Zob. J. Nawracała, op. cit., s. 38-39.

37. Zob. więcej: M.P. Ziemiak, Pre-contractual information duties of insurers. A German and Polish approach, „Prawo Asekuracyjne" 2019, nr 2, s. 152 i nast. 
do jej art. 18, przyjać należy, że wskazane informacje powinny zostać przekazane odpowiednio wcześnie przed zawarciem umowy, tj. w taki sposób, aby klient mógł zapoznać się z nimi, ergo: uwzględnić je przy podejmowaniu decyzji, czy umowę w ogóle zawierać ${ }^{38}$. Trafnie podkreśla się także, iż przekazanie omawianych informacji odpowiednio wcześnie, lecz w sposób utrudniający lub uniemożliwiający swobodne zapoznanie się z nimi, można uznać za naruszenie interesów klientów ${ }^{39}$. Nadto w przypadku ubezpieczeń z elementem informacyjnym, analizowane obowiązki stanowia jeden z mechanizmów identyfikowania i eliminowania konfliktów interesów ${ }^{40}$.

Na wstępie omówić należy wymogi formalne wynikające z przepisów ustawy dystrybucyjnej, a odnoszące się do zagadnienia wynagrodzenia pośredników (przy czym uwagi te odnosić się będa siłą rzeczy także do innych informacji, które dystrybutor musi przekazać klientowi we wspomnianym „pakiecie”]. Forma przekazania informacji, w tym tych o wynagrodzeniu, została ustalona w art. 9 ust. 1 u.d.u. Zgodnie z tym przepisem informacje przekazać należy w postaci papierowej, nieodpłatnie i w języku urzędowym państwa członkowskiego Unii Europejskiej, w którym umowa ubezpieczenia lub umowa gwarancji ubezpieczeniowej jest zawierana (lub w innym języku, na który wyraża zgodę strony umowy), przy czym informacje te powinny być jasne, rzetelne i niewprowadzające w błąd.

Podstawowym sposobem przekazania informacji jest wręczenie ich klientowi w postaci papierowej, tj. w formie wydruku ${ }^{41}$, przy czym wydruk ten nie musi być opatrzony podpisem, gdyż nie należy utożsamiać wspomnianej postaci papierowej z forma pisemną czynności prawnej, o której mowa w art. 78 k.c. ${ }^{42}$ Informacje muszą być więc utrwalone na papierze, a samo ich przekazanie nie może wiązać się z jakimikolwiek kosztami po stronie klienta. Zastosowanie innego niż papier trwałego nośnika do przekazania informacji o wynagrodzeniu jest możliwe tylko po spełnieniu następujacych przesłanek:

- na żądanie klienta, pod warunkiem że dystrybutor ubezpieczeń (w tym pośrednik) zapewnił mu wybór między informacjami w postaci papierowej a informacjami na innym trwałym nośniku (niemniej klient, który zgodził się na inny niż papier nośnik informacji, i tak może zażądać późniejszego przekazania mu informacji na papierze, a dystrybutor musi takiemu obowiązkowi zadośćuczynić);

- w przypadku innego trwałego nośnika wymagającego dostępu do internetu - jeżeli klient posiada regularny dostęp do internetu, przy czym zgodnie z art. 9 ust. 6 u.d.u. za dowód posiadania przez klienta takiego regularnego dostępu uznaje się w szczególności podanie przez niego, na potrzeby danej transakcji, adresu poczty elektronicznej.

38. Analogicznie jak w przypadku doręczania ogólnych warunków ubezpieczenia przez zakład ubezpieczeń zob. więcej na temat art. 9 ust. 1 u.d.u. i zestawienia tego przepisu z art. 384 k.c. dotyczącego doręczania wzorców umownych w M.P. Ziemiak, Informacja o produkcie ubezpieczeniowym i tzw. karta informacyjna produktu. Kilka uwag na tle artykułów 8 i 9 ustawy o dystrybucji ubezpieczeń, [w:] Insurance Challenges of Anno Domini 2018, [red.] K. Malinowska, A. Tarasiuk, AIDA, Warszawa 2018, s. 119-120.

39. Zob. M. Oko, [w:] Ustawa o dystrybucji..., [red.] P. Machulak, J. Ziemba, s. 178.

40. Zob. dalsze uwagi na temat art. 15 ust. 4 ustawy dystrybucyjnej.

41. Zob. M. Prętki, [w:] Nowe zasady..., s. 144.

42. Zob. J. Nowak, [w:] Ustawa o dystrybucji ..., [red.] P. Czublun, s. 119. 
Dodatkowo informacje o wynagrodzeniu moga być przekazywane za pośrednictwem strony internetowej pośrednika, przy czym może być strona „spersonalizowana” dla danego klienta ${ }^{43}$ lub ogólnodostępna, jeżeli spełnia określone w ustawie dystrybucyjnej warunki ${ }^{44}$. W drugim przypadku trzeba zauważyć, że informacje dotyczące wynagrodzenia powinny być eksponowane na stronie WWW w sposób stały, tak aby klient miał dostęp do nich w każdym czasie. W ustawie mowa tu o okresie, w którym klient ma potrzebę zapoznania się z informacjami. Jak się wydaje, chodzi zarówno o okres obowiązywania umowy ubezpieczenia lub gwarancji zawartej przez klienta, jak i o okres przedawnienia roszczeń przeciwko dystrybutorowi (w tym pośrednikowi) ${ }^{45}$.

W przypadku dystrybucji ubezpieczeń za pomocą środków porozumiewania się na odległość - zgodnie z art. 9 ust. $?$ u.d.u. - do przekazywania informacji o wynagrodzeniu stosuje się przepisy ustawy z dnia 30 maja 2014 roku o prawach konsumenta ${ }^{46}$, a dokładnie przepisy o umowach dotyczących usług finansowych zawieranych na odległość. Oznacza to, że informacja o wynagrodzeniu powinna zostać przekazana klientowi zgodnie z dyspozycją art. 39 ust. 1 wraz z danymi, o których mowa w tym przepisie, co do zasady w sposób utrwalony na papierze i przed zawarciem umowy ${ }^{47}$. Jeżeli zaś umowa jest na życzenie klienta zawierana z zastosowaniem środka porozumiewania się na odległość, który nie pozwala na przekazanie wskazanych informacji na papierze lub innym trwałym nośniku przed zawarciem umowy, informacje winny zostać przekazane niezwłocznie po jej zawarciu (art. 39 ust. 3 in fine u.p.k.) ${ }^{48}$.

Odnośnie do wskazanych w art. 9 ust. 1 in fine sui generis kryteriów jakościowych przekazywanych informacji (jasność, rzetelność itd.), to chodzi tu o zapewnienie pełności oraz uczciwości przekazu ujętego w samej informacji, a także o transparentność użytego języka, np. niestosowanie żargonu ubezpieczeniowego czy zwrotów niejednoznacznych ${ }^{49}$. Choć ustawa dystrybucyjna nie określa tu drobiazgowych wymogów dotyczących chociażby rozmiaru czy kolorystyki czcionki, należy przyjać, że aby interes klienta został należycie zabezpieczony, również warstwa graficzna nośnika, za pomocą którego informacje sa przekazywane, musi być odpowiednio czytelna.

Obowiązki informacyjne, w tym te dotyczące wynagrodzeń, odnoszą się do wszystkich umów ubezpieczenia, niezależnie od tego, czy klientem jest konsument, czy profesjonalista, oraz czy mamy do czynienia z umową ubezpieczenia dobrowolnego, czy obowiązkowego. Jedyny wyjątek stanowią tu umowy ubezpieczenia lub gwarancji ubezpieczeniowej obejmujące duże ryzyka w rozumieniu art. 3 ust. 1 pkt 6 u.dz.u.r.

43. Chodzi tu o stronę, na której informacje są skierowane bezpośrednio do konkretnego, zindywidualizowanego klienta, w rozumieniu art. 9 ust. 4 pkt 1 u.d.u. (np. klient otrzymuje login i hasło do „portalu klienta”, w którym umieszczono pakiet informacji adresowany tylko dla niego).

44. Tj.: 1) klient wyraził zgodę na przekazanie tych informacji za pośrednictwem strony internetowej, 2) klient posiada regularny dostęp do internetu, 3) klient został powiadomiony droga elektroniczna (np. poprzez e-mail lub SMS) o adresie strony internetowej oraz miejscu na tej stronie, gdzie zostały udostępnione te informacje (chodzi więc o wskazanie konkretnej „zakładki” na stronie www, gdzie umieszczono informacje), 4) dystrybutor zapewni dostępność tych informacji na stronie internetowej w okresie, w którym klient może w normalnych okolicznościach mieć potrzebę zapoznania się z nimi.

45. Zob. J. Ziemba, [w:] Ustawa o dystrybucji ..., [red.] P. Machulak, J. Ziemba, s. 90.

46. Tekst jedn. Dz. U. 2017, poz. 683 (dalej: u.p.k.).

47. Zob. M.P. Ziemiak, nformacja o produkcie ..., s. 119.

48. Zob. M. Prętki, op. cit., s. 145.

49. Zob. M.P. Ziemiak, Informacja o produkcie ..., s. 119-120. 
Przejdźmy do treści samego obowiązku informacyjnego: zgodnie z art. 22 ust. 1 pkt. 5 u.d.u. przed zawarciem umowy ubezpieczenia lub umowy gwarancji ubezpieczeniowej agent ubezpieczeniowy albo agent oferujący ubezpieczenia uzupełniające informuje klienta o charakterze wynagrodzenia otrzymywanego w związku z proponowanym zawarciem umowy ubezpieczenia lub umowy gwarancji ubezpieczeniowej, w szczególności zaś informuje, czy agent otrzymuje:

- honorarium płacone bezpośrednio przez klienta,

- prowizję dowolnego rodzaju uwzględnioną w kwocie składki ubezpieczeniowej,

- inny rodzaj wynagrodzenia,

- wynagrodzenie stanowiące połączenie wskazanych rodzajów wynagrodzenia.

Analogiczna regulacja dotycząca brokerów ubezpieczeniowych znalazła się w art. 32 ust. 1 pkt 6 ustawy dystrybucyjnej. Dodatkowo agent ubezpieczeniowy (ale także sam zakład ubezpieczeń oraz broker ubezpieczeniowy ${ }^{50}$ przed zawarciem umowy ubezpieczenia na życie, o której mowa w grupie 3 działu I załącznika do u.dz.u.r., informuje klienta również o wysokości wskaźnika kosztów dystrybucji ${ }^{51}$ związanych z proponowaną umową. Zgodnie z definicją wskaźnika kosztów dystrybucji jest on ustalany przy „tworzeniu produktu ubezpieczeniowego” z uwzględnieniem m.in. kosztów akwizycji. Stąd wskaźnik taki jest ustalany przez twórcę produktu, którym w polskich realiach jest przede wszystkim zakład ubezpieczeń. W tym zakresie jest więc konieczne ścisłe współdziałanie ubezpieczycieli z pośrednikami, tak aby obowiązek informacyjny wobec klienta został należycie zrealizowany. Inaczej mówiąc, pośrednicy powinni otrzymywać od zakładów ubezpieczeń precyzyjne informacje o wskaźniku kosztów dystrybucji, a następnie przekazać je klientowi.

Pośrednicy obowiązani są podawać informacje o charakterze wynagrodzenia, ale nie o jego wysokości. Jak się wydaje, spełnieniem obowiązku informacyjnego - np. przez agenta ubezpieczeniowego - będzie przekazanie klientowi, że „Agent tytułem wynagrodzenia otrzymywanego w związku z proponowanym zawarciem umowy ubezpieczenia lub umowy gwarancji ubezpieczeniowej otrzymuje prowizję od zakładu ubezpieczeń, uwzględnioną w kwocie składki ubezpieczeniowej". Jedynym wyjątkiem jest przypadek, w którym honorarium płacone jest bezpośrednio przez klienta (co jednak zdarza się stosunkowo rzadko) - należy wówczas określić wysokość wynagrodzenia lub sposób jego wyliczenia, jeśli podanie konkretnej kwoty nie jest możliwe. Stąd w sytuacji, w której np. klient zleca brokerowi wykonanie dodatkowo płatnych ekspertyz czy opinii dotyczących zawieranych lub już zawartych umów ubezpieczenia, informacja powinna uwzględniać wskazane elementy. Problem w tym, że często podanie konkretnej kwoty może okazać się niemożliwe. W takiej sytuacji należałoby wskazać czytelny i w miarę precyzyjny sposób ustalania wynagrodzenia, np. stawkę godzinową czy odwołanie się do konkretnych kosztorysów.

W tym miejscu należy postawić pytanie: jak daleko sięga obowiązek informacyjny w zakresie wynagrodzenia? Po pierwsze, art. 22, 23 i 32 ustawy dystrybucyjnej odnoszą się do konkretnej umowy ubezpieczenia. Oznacza to, że obowiązek informacyjny może być zróżnicowany w zależności od tego, w jaki sposób ukształtowano sposób wynagrodzenia pośrednika z tytułu zawarcia

50. Zob. analogiczne do art. 22 ust. 2 przepisy art. 23 ust. 2 oraz 32 ust. 2 ustawy dystrybucyjnej.

51. Zgodnie z art. 3 ust. 1 pkt 23 u.dz.u.r. wskaźnik kosztów dystrybucji to wyrażony procentowo z dokładnością do dwóch miejsc po przecinku iloraz przyjętych przy tworzeniu produktu kosztów akwizycji, o których mowa w przepisach o rachunkowości zakładów ubezpieczeń, dla danej umowy ubezpieczenia oraz sumy należnych składek ubezpieczeniowych z tytułu danej umowy ubezpieczenia w rekomendowanym minimalnym okresie trwania umowy. 
danej umowy, ergo zmianie ulegać może treść informacji stosowana przez tego samego pośrednika czy ubezpieczyciela. Przykładowo, jeżeli poza podstawową prowizją agent może otrzymać nagrodę lub nadprowizję z tytułu osiągnięcia konkretnego wyniku sprzedaży, to wydaje się, że informacja o możliwości uzyskania nagrody powinna zostać przekazana klientowi ${ }^{52}$. Po drugie, konieczność przekazania takiej informacji zaistnieje tylko wtedy, kiedy agent ma pewność, iż nagrodę lub nadprowizję może rzeczywiście uzyskać (a więc np. po ogłoszeniu przez ubezpieczyciela stosownego konkursu sprzedażowego w swojej sieci agencyjnej]. Po trzecie, nawet w ramach portfela konkretnych umów ubezpieczenia zakres obowiązku informacyjnego może ulegać zmianie, w zależności chociażby od częstotliwości organizowania przez ubezpieczyciela konkursów sprzedażowych dotyczących danych umów. Po czwarte, jeżeli po zawarciu umowy dojdzie do zmiany sposobu wynagradzania, ustawa dystrybucyjna nie przewiduje obowiązku informowania klientów o tej zmianie. Po piąte, w doktrynie podnosi się, że informacja o charakterze wynagrodzenia powinna uwzględniać też częstotliwość jego wypłacania (np. wynagrodzenie jednorazowe) ${ }^{53}$. Po szóste, art. 22, 23 i 32 ustawy dystrybucyjnej nie wymagają ujawniania szczegółowych informacji o warunkach czy przesłankach nabycia wynagrodzenia ${ }^{54}$.

Dodatkowy obowiązek informacyjny pojawia się w przypadku ubezpieczeń, o których mowa w grupie 3 działu I załącznika do u.dz.u.r. Otóż jeżeli rozwiązania organizacyjne mające zapobiegać konfliktom interesów okażą się niewystarczające, aby zapewnić uniknięcie ryzyka naruszenia interesów klienta ${ }^{55}$, agent ubezpieczeniowy, broker ubezpieczeniowy i zakład ubezpieczeń przed zawarciem umowy ubezpieczenia ujawniają klientowi ogólny charakter lub źródła konfliktu interesów, w tym w szczególności informuja, czy uzyskiwana prowizja z tytułu umowy ubezpieczenia jest uzależniona od wolumenu zawartych umów ubezpieczenia. Trafnie zauważa się w piśmiennictwie, że wskazany obowiązek informacyjny powinien być brany pod uwagę tylko w przypadku spełnienia się warunku braku stosownych rozwiązań organizacyjnych (nie jest to więc obowiązek o charakterze stałym ${ }^{56}$. Problem tkwi jednak w tym, że - jak słusznie zauważa Anna Urbańczyk - „Zasadniczo bowiem zawsze wielkość uzyskiwanej przez dystrybutora prowizji zależy od liczby lub wartości zawartych przezeń umów ubezpieczenia. Jeżeli wysokość prowizji została określona stałą stawką procentową, wielkość wynagrodzenia w sposób oczywisty zwiększa się wraz z wzrostem liczby zawartych umów ubezpieczenia lub ich wartości" ${ }^{5 ?}$. Cytowana Autorka wywodzi więc, że dyspozycją art. 15 ust. 4 ustawy dystrybucyjnej objęta jest sytuacja, w której wraz ze wzrostem wolumenu zawartych umów wzrasta też stawka prowizji, przy czym nawet w takiej sytuacji konieczna jest całościowa analiza, czy takie rozwiązanie uznać można za konflikt interesów ${ }^{58}$.

52. M. Szczepańska wskazuje, że w przypadku kiedy wynagrodzenie agenta lub brokera ubezpieczeniowego obejmuje prowizję dowolnego rodzaju uwzględnioną w kwocie składki ubezpieczeniowej, informacją należy objąć zarówno tzw. prowizje wyliczane bezpośrednio [„od sprzedaży polis”], jak i te wyliczane pośrednio (np. „premie produktowe" zależne od wyników sprzedaży danego produktu), zob. M. Szczepańska, op. cit., s. 28.

53. Ibidem, s. 28.

54. Ibidem.

55. Ponieważ szczegółowe omówienie zagadnienia konfliktu interesów znacznie wykraczałoby poza ramy niniejszego opracowania szerzej zob. A. Urbańczyk, [w:] Nowe zasady dystrybucji..., s. 156 i nast.

56. Zob. M. Oko, op. cit., s. 137-138.

57. Zob. A. Urbańczyk, op. cit., s. 160.

58. Ibidem, s. 161. 
Wreszcie, odnośnie do obowiązków informacyjnych zakładów ubezpieczeń regulacja art. 23 ust. 1 pkt 2 ustawy dystrybucyjnej jest nieco mniej szczegółowa. Zgodnie z tym przepisem przed zawarciem umowy ubezpieczenia lub umowy gwarancji ubezpieczeniowej zakład ubezpieczeń informuje klienta o charakterze wynagrodzenia otrzymywanego przez osoby wykonujące czynności dystrybucyjne zakładu ubezpieczeń w związku z proponowanym zawarciem umowy ubezpieczenia lub umowy gwarancji ubezpieczeniowej. Ustawodawca nie sprecyzował, jaką formę może przybrać takie wynagrodzenie. Skoro jednak - jak przyjęto wcześniej - osoby wykonujące czynności dystrybucyjne zakładu ubezpieczeń muszą posiadać status pracownika w rozumieniu przepisów prawa pracy, to informacja przekazywana przez zakład ubezpieczeń powinna wskazywać, że ich wynagrodzenie wynika ze stosunku pracy. Wynagrodzenie takie może zawierać zarówno składniki stałe, jak i zmienne ${ }^{59}$.

\section{Podsumowanie}

Mimo wejścia w życie ustawy dystrybucyjnej, istota i charakter prawny wynagrodzenia zarówno pośredników ubezpieczeniowych, jak i pracowników zakładów ubezpieczeń nie uległy zmianie. Nowościa jest zapewne pojawienie się ustawowych kryteriów ich kształtowania, choć nie zawsze są to kryteria czytelne i jednoznaczne - jest tak chociażby w przypadku wspomnianego braku definicji pojęcia „zachęty” na gruncie art. 7 ust. 2 czy niezbyt precyzyjnej definicji samego wynagrodzenia. Dodatkowo wzmożony został obowiązek informacyjny, którego idea jest m.in. zapewnienie maksymalnej transparentności transakcji ubezpieczeniowych, szczególnie w tych sektorach rynku, w których kwestia wynagradzania pośredników wywoływała wątpliwości i kontrowersje (np. przy oferowaniu ubezpieczeń z UFK).

Niemniej podmioty polskiego rynku ubezpieczeń nadal dysponują sporym marginesem swobody w kształtowaniu wynagrodzeń odnoszących się do dystrybucji ubezpieczeń, zaś omówione w niniejszym artykule przepisy traktować należy jako swoiste bezpieczniki, zapewniające zgodność przyjmowanych rozwiązań z prawem i standardami europejskimi.

Wreszcie, mając na uwadze ogólny charakter uregulowania art. 7 ust. 2 ustawy dystrybucyjnej, szczególne znaczenie dla ukształtowania zasad wynagradzania pośredników ubezpieczeniowych w nowej rzeczywistości prawnej będą zapewne miały standardy rynkowe, zwłaszcza te wypracowane przez zakłady ubezpieczeń.

\section{Wykaz źródeł}

Kowalewski E., Wynagrodzenie brokera ubezpieczeniowego, „Prawo Asekuracyjne” 2008, nr 2. Malinowska K., Najlepszy interes klienta - rozważania na tle ustawy o dystrybucji ubezpieczeń,

[w: Dystrybucja usług ubezpieczeniowych. Wybrane zagadnienia prawne, Gnela B., Szaraniec M. [red.], DIFIN, Warszawa 201 ?

Nawracała J., Wynagrodzenie w dystrybucji (cz. 2), „Miesięcznik Ubezpieczeniowy” 2017, nr 12.

59. Zob. J. Pokrzywniak, op. cit., s. 149. 
Nowe zasady dystrybucji ubezpieczeń. Zagadnienia prawne, Pokrzywniak J. [red.], Wolters Kluwer, Warszawa 2018.

Orlicki M., Aksjologia dystrybucji ubezpieczeń - kryteria uznawania działań dystrybutora za zgodne z prawem i etyczne, [w:] Dystrybucja usług ubezpieczeniowych. Wybrane zagadnienia prawne, Gnela B., Szaraniec M. [red.], DIFIN, Warszawa 2017.

Prawo ubezpieczeń gospodarczych, Kowalewski E. [red.], Oficyna Wydawnicza Branta, BydgoszczToruń, 2006.

Prawo ubezpieczeń gospodarczych. Tom I. Komentarz, Brodecki Z., Glicz M., Serwach M. [red.], Wolters Kluwer, LEX/El. 2010.

Szczepańska M., Wynagrodzenie brokera ubezpieczeniowego w świetle ustawy o dystrybucji ube-

zpieczeń, „Prawo Asekuracyjne” 2018, nr 3.

Ustawa o dystrybucji ubezpieczeń. Komentarz, Czublun P. [red.], CH Beck, Warszawa 2018.

Ustawa o dystrybucji ubezpieczeń. Komentarz, Machulak P., Ziemba J. [red.], CH Beck, Warszawa 2018.

Ustawa o działalności ubezpieczeniowej i reasekuracyjnej. Komentarz, Szczepańska M., Wajda P. [red.], Wolters Kluwer, Warszawa 201 .

Ziemiak M.P., Informacja o produkcie ubezpieczeniowym i tzw. karta informacyjna produktu. Kilka uwag na tle artykułów 8 i 9 ustawy o dystrybucji ubezpieczeń, [w:] Insurance Challenges of Anno Domini 2018, Malinowska K., Tarasiuk A. [red.], AIDA, Warszawa 2018.

Ziemiak M.P., Pre-contractual information duties of insurers. A German and Polish approach, „Prawo Asekuracyjne" 2019, nr 2.

\section{Remuneration of insurance intermediary in the context of insurance distribution act. Selected issues}

Insurance distribution act - unlike its predecessor (act on insurance intermediation) - contains a number of provisions that refer directly to the issue of remuneration of both insurance intermediaries (agents and brokers] as well as insurers' employees. Said provisions can be divided into two main categories, i.e. setting of remuneration and information obligations related to remuneration. These are the issues devoted to this paper. At the beginning, general remarks that concern remuneration of insurance intermediaries and persons with the help of which insurers perform distribution activities are presented. Further parts include the analysis of art. 7 par. 2 of the distribution act and mentioned information obligations (articles 22, 23 and 32). The paper closes with a summary, containing the author's conclusions and comments.

Key words: intermediaries, remuneration, commission, brokerage, agents, brokers, insurers, insurance distribution.

DR MICHAŁ P. ZIEMIAK - Katedra Prawa Ubezpieczeniowego UMK w Toruniu, radca prawny. mpz@umk.pl https://orcid.org/0000-0001-8543-9458 
